\title{
Peningkatan Pemahaman Orang Tua dalam Mengidentifikasi Terjadinya Tindakan Kekerasan Seksual Terhadap Anak di Kecamatan Pauh
}

\author{
Fachrina, Yulkardi, dan Afrizal \\ Fakultas Ilmu Sosial dan Ilmu Politik, Universitas Andalas, Kampus Limau Manis, Padang, 25163. Indonesia \\ E-mail: fachrinasos@gmail.com
}

Keywords: children, sexual violence, parent, perpetrator

\begin{abstract}
A sexual violence against children can occur anywhere, either in the family environment (private space) or in the neighborhood, work environment, school and other public spaces. Where the perpetrator is the majority of people closest to the victim, example father, uncle, brother or neighboor. For this reason, an increase in parental understanding in identifying the occurrence of sexual violence against children is needed because it is a serious problem that has a negative impact. The purpose of this service activity was to motivate and encourage parents to have a correct understanding in the management of sexual violence against children. It was held by distributed the information to target home and followed by discussion and consultation virtually. The target audience is parents in the Cupak Tangah sub-district who have children less than 17 years of age. This activity has been the parent's awareness in the occurrence of acts of sexual violence against children.
\end{abstract}

\footnotetext{
ABSTRAK

Kekerasan seksual terhadap anak dapat terjadi dimana saja, baik pada ruang privat seperti lingkungan keluarga atau pun ruang publik seperti lingkungan tempat tinggal, lingkungan kerja, sekolah dan tempat umum lainnya. Dimana pelakunya mayoritas adalah orang terdekat korban seperti ayah, paman, saudara, teman atau tetangga. Untuk itu peningkatan pemahaman orang tua dalam mengidentifikasi atau menemukenali terjadinya kekerasan seksual terhadap anak diperlukan karena hal tersebut merupakan persoalan serius yang berdampak negatif. Tujuan pelaksanaan kegiatan pengabdian ini adalah memberdayakan orang tua agar mempunyai pemahaman dalam mengidentifikasi tanda-tanda terjadinya kekerasan seksual pada anak dan cara-cara atau upaya dalam menangani kekerasan seksual jika terjadi pada anak mereka. Dengan demikian orang tua dapat melakukan langkah yang tepat dan cepat dalam menangani terjadinya tindakan kekerasan seksual terhadap anak. Metode pelaksanaan yaitu mendistribusikan leaflet berisikan materi penyuluhan dari rumah ke rumah khalayak sasaran, dan diikuti dengan diskusi atau konsultasi secara daring. Khalayak sasaran yaitu orang tua di Kelurahan Cupak Tangah yang mempunyai anak berusia di bawah 17 tahun. Kegiatan pengabdian telah membangun kesadaran orang tua dalam penanganan terjadi tindakan kekerasan seksual terhadap anak.
} 


\section{PENDAHULUAN}

Sejumlah kasus kekerasan seksual belakangan ini diketahui dari berbagai media massa sering terjadi terhadap anak, remaja, maupun orang dewasa khususnya perempuan yang terjadi di rumah dan di ruang publik. Berdasarkan data kekerasan seksual selama tahun 2019 yang didampimgi lembaga WCC Nurani Perempuan Sumatera Barat yaitu terdapat sebanyak 51 kasus, terdiri dari perkosaan, kehamilan tidak diinginkan, eksploitasi seksual, sodomi, pernikahan anak dan trafficking tujuan seksual. Dimana pelaku kekerasan seksual yang dilakukan suami sebanyak 39 kasus, ayah kandung 8 kasus, pacar dan teman 17 kasus, tetangga 14 kasus dan terdapat juga oleh majikan sebanyak 6 kasus serta lainnya seperti ayah tiri, abang kandung, kakek korban, mantan suami, penjaga sekolah, mucikari dan orang yang baru dikenal korban. Hal ini menunjukkan bahwa dalam banyak kasus, pelaku kekerasan seksual cenderung oleh orang-orang terdekat korban itu sendiri.

Untuk Kota Padang sendiri kasus terburuk yaitu pencabulan oleh caleg untuk DPRD Kota Padang berusia 57 tahun mencabuli 2 anak perempuan berusia 8 dan 11 tahun dengan mengancam korban dan menjanjikan selalu memberikan uang jajan dan seorang Ayah yang memperkosa 2 orang anak kandungnya berulangkali di tahun 2020 (liputan6.com). Akan tetapi masih banyak kasus yang tidak muncul ke permukaan dan tidak dilaporkan ke polisi karena ketakutan yang dialami korban. Di samping itu orang tua korban juga menganggap hal ini merupakan aib bagi keluarga mereka.

Berbagai upaya telah dilakukan baik oleh Pemerintah maupun lembaga-lembaga non pemerintah dalam pencegahan dan penanggunggan tindakan kekerasan seksual (lihat Fachrina dkk, 2019). DPR juga telah mengesahkan UU Nomor 17 Tahun 2016 tentang Perlindungan Anak. Akan tetapi kekerasan seksual terus mengalami peningkatan setiap tahunnya (Catahu Komnas Perempuan, 2020). Peningkatan pemahaman orang tua dalam mengidentifikasi atau menemukenali terjadinya kekerasan seksual terhadap anak diperlukan karena hal tersebut merupakan persoalan serius yang berdampak negatif, tapi di satu sisi orang tua relatif kurang mempunyai pemahaman mengenai mengenai kekerasan seksual itu sendiri (Macdaliza, 2016). Kekerasan seksual merupakan tindakan yang mengarah ke ajakan/desakan seksual seperti menyentuh, meraba, mencium, dan atau melakukan tindakan-tindakan lain yang tidak dikehendaki oleh korban, memaksa korban menonton produk pornografi, gurauan-gurauan seksual, ucapan-ucapan yang merendahkan dan melecehkan dengan mengarahkan ke tindak praktik kekerasan seksual (Poerwandari, 2000).

Berkaitan dengan hal tersebut, sudah seharusnya orang tua mendapatkan informasi yang lengkap, benar dan akurat mengenai hal-hal yang berkaitan dengan kekerasan seksual pada anak. Diperkuat dengan data yang ada bahwa pelaku kekerasan ini cenderung orang terdekat yang masih memiliki hubungan keluarga dengan korban seperti paman, guru bahkan ayah kandung sendiri. Tugas dan tanggungjawab kita bersama untuk dapat memberikan pemahaman kepada orang tua agar dapat mengidentifikasi tanda-tanda anak mengalami kekerasan seksual.

Tujuan pelaksanaan kegiatan pengabdian ini adalah memberdayakan orang tua agar mempunyai pemahaman dalam mengidentifikasi tanda-tanda terjadinya kekerasan seksual pada anak dan cara-cara atau upaya dalam menangani kekerasan seksual jika terjadi pada anak mereka. Dengan demikian orang tua dapat melakukan langkah yang tepat dan cepat dalam menangani jika terjadinya tindakan kekerasan seksual terhadap anak. 


\section{METODE}

Masalah dipecahkan dengan menggunakan kerangka pemecahan masalah sebagai berikut: 1). Memberikan pemahaman kepada orang tua mengenai tanda-tanda atau karakteristik dan gejala anak mengalami kekerasan seksual, 2). Memotivasi dan mendorong orang tua untuk mempunyai pemahaman yang tepat dan cepat dalam penanganan tindakan kekerasan seksual jika terjadi pada anak.

Berdasarkan kerangka pemecahan masalah seperti yang dijelaskan di atas maka metode pelaksanaan kegiatan dilakukan melalui penyuluhan. Kemudian dilanjutkan dengan kegiatan diskusi bersama. Diskusi dilakukan untuk menyepakati tanda-tanda terjadinya kekerasan seksual dan merumuskan langkah-langkah yang tepat dan cepat dalam penanganan terjadinya tindakan kekerasan seksual terhadap anak. Adapun sasaran kegiatan ini adalah orang tua yang mempunyai anak berumur 17 tahun ke bawah dan berdomisili di sekitar Kecamatan Pauh Kota Padang, tepatnya di Kelurahan Sungai Balang. Kegiatan ini dilaksanakan oleh salah satu tim Pengabdian kepada Masyarakat dari jurusan Sosiologi, Unand.

\section{HASIL DAN PEMBAHASAN}

\section{A. Tahapan Persiapan}

Pada tahapan persiapan ini merupakan tahapan yang digunakan untuk merencanakan dan menyiapkan berbagai keperluan yang dibutuhkan sebelum pelaksanakan kegiatan di lapangan. Seperti kegiatan pertemuan antara tim pengabdian/rapat tim untuk membahas berbagai hal yang perlu disiapkan sebelum melakukan pengabdian. Pertemuan selanjutnya dilakukan dalam rangka menyusun materi dan metode pengabdian. Pertemuan ini menyepakati bahwa;

1. Pengabdian akan dilaksanakan untuk pemberian materi secara daring.

2. Materi pengabdian sesuai dengan yang sudah direncanakan difokuskan pada pengenalan tanda-tanda anak mengalami kekerasan seksual dan tindakan yang perlu dilakukan orang tua jika anaknya mengalami kekerasan seksual, dalam upaya meningkatkan kesadaran orang tua dalam melindungi anak dari tindakan kekerasan seksual.

3. Tim pengabdi bertindak sebagai fasilitator.

\section{B. Tahapan Pra kegiatan}

Sebelum pelaksanaan kegiatan, dilakukan kembali koordinasi dengan pihak kelurahan terkait kelengkapan administarsi, peserta kegiatan, dan waktu pelaksanaan kegiatan. Selanjutnya setelah memperoleh kepastian jadwal pelaksanaan kegiatan, maka dilakukanlah berbagai persiapan lain seperti surat tugas, absen, dan memperbanyak materi pengabdian, serta berbagai keperluan lain yang digunakan dalam kegiatan. Dalam hal ini persiapan dan pelaksanaan kegiatan dibantu oleh dua orang mahasiswa.

\section{Tahap Pelaksanaan Kegiatan}

Setelah berkoordinasi dengan pihak kelurahan akhirnya diputuskan bahwa pelaksanaan kegiatan tidak dapat dilakukan seperti biasanya yaitu melalui ceramah tatap muka dengan menghadirkan beberapa orang khalayak sasaran. Berdasarkan pertimbangan menyangkut situasi dan kondisi pandemi Covid-19 yang sedang mewabah dan mengalami peningkatan serta juga atas dasar himbaun pemerintah daerah untuk tidak mengadakan kegiatan yang menghimpun masa maka tim pengabdi dan pihak kelurahan bersepakat melakukan kegiatan pengabdian secara daring dengan menggunakan media sosial. Kegiatan direncanakan menggunakan zoom untuk menyampaikan materi pengabdian. Akan tetapi ternyata setelah 
menghubungi pihak-pihak atau peserta yang akan mengikuti kegiatan yaitu orang tua yang terdiri dari ibu-ibu rumah tangga di kelurahan mengalami kesulitan mengkoordinasikan waktu untuk mengikuti ini. Oleh karena itu untuk mempermudah pelaksanaan dan penyampain materi maka penyampaian materi dilakukan dengan membagikan artikel materi ke peserta secara langsung ke rumah-rumah mereka. Artikel materi ditulis, menjelaskan tentang kekerasan seksual, dampaknya dan langkah-langkah yang perlu dilakukan orang tua dan anak dalam mencegah atau mengantsipasi terjadinya kekerasan seksual. Materi juga menjelaskan tentang ciri-ciri anak mengalami kekerasan seksual dan bagaimana seharusnya tindakan orang tua dalam menanganinya. Ringkasan materi pengabdian berdasarkan modul yang disusun oleh Meri Naherta dalam modul Intervensi Pencegahan Kekerasan Seksual Terhadap Anak (2017) tergambar dalam table-tabel berikut.

Tabel 1. Karakteristik Pelaku dan Korban Kekerasan Seksual

\begin{tabular}{|c|l|}
\hline No. & \multicolumn{1}{|c|}{ Mengenali Karakteristik Pelaku Kekerasan Seksual } \\
\hline 1. & $\begin{array}{l}\text { Pelaku biasanya sangat pintar dalam merayu korbannya, dan merayu anak-anak secara } \\
\text { bertahap. }\end{array}$ \\
\hline 2. & Pelaku cenderung memilih anak yang tidak berdaya dan penurut. \\
\hline 3. & $\begin{array}{l}\text { Pelaku akan memberikan perhatian khusus kepada anak seperti sering memberi hadiah } \\
\text { atau uang. }\end{array}$ \\
\hline 4. & $\begin{array}{l}\text { Pelaku berusaha melakukan pendekatan pada orang tua calon korban, menunjukkan } \\
\text { sikap tulus sehingga orang tua percaya kepada pelaku untuk menjaga atau berteman } \\
\text { dengan anak kita. Setelah mendapat kepercayaan dari keluarga, maka pelaku mulai } \\
\text { memanfaatkan anak, menciptakan keakraban dengan anak atau menjadi guru dan } \\
\text { mengajak permainan tertentu yang mengarah ada aspek seksualitas. }\end{array}$ \\
\hline 5. & $\begin{array}{l}\text { Setelah melakukan aksinya (pemerkosaan, mencabuli, pelecehan seksual dll), biasanya } \\
\text { pelaku akan mengancam, memeras atau menyalahkan anak. "Jika kamu kasih tau mama } \\
\text { papa, maka saya akan bunuh mereka", atau "awas ya ini rahasia kita berdua, kamu nanti } \\
\text { bisa masuk penjara" dll. }\end{array}$ \\
\hline
\end{tabular}

Tabel 2. Tanda Anak ketika Menjadi Korban Kekerasan Seksual

\begin{tabular}{|c|l|}
\hline No. & Mengenali Tanda Anak jika Menjadi Korban Kekerasan Seksual \\
\hline 1. & $\begin{array}{l}\text { Mengamati tanda tanda yang kelihatan atau tampak, mencurigakan dan terlihat terus } \\
\text { menerus. }\end{array}$ \\
\hline 2. & $\begin{array}{l}\text { Adanya perubahan sikap yang drastis dan mendadak pada anak, seperti biasanya ceria } \\
\text { menjadi pemurung atau pemarah, sering menangis tanpa sebab. }\end{array}$ \\
\hline 3. & Anak mengeluhkan rasa sakit di badannya atau di alat kelaminnya. \\
\hline 4. & Anak mengompol, padahal sebelumnya tidak ada. \\
\hline 5. & Prestasi belajar anak menurun dan anak malas sekolah atau belajar. \\
\hline 6. & Nafsu makan anak berkurang. \\
\hline 7. & Anak tidak ingin ditinggalkan sendiri. \\
\hline 8. & Anak menuntut perhatian lebih. \\
\hline 9. & Tanda yang tidak jelas atau tidak kelihatan bahwa anak kita mengalami kekerasan \\
\hline
\end{tabular}


seksual yaitu anak bersikap manis dan patuh, berusaha agar tidak menjadi pusat perhatian karena anak berusaha menyimpan rahasia pelecehan seksual yang dialaminya.

Tabel 3. Tindakan yang Harus Dilakukan Orang Tua

\begin{tabular}{|c|c|}
\hline No. & $\begin{array}{l}\text { ndakan yang Harus Dilakukan Orang Tua Jika Terjadi Tindakan Kekeras } \\
\text { ksual pada Anak }\end{array}$ \\
\hline 1. & $\begin{array}{l}\text { la terdapat beberapa tanda di atas, sebaiknya orangtua segera membawa anak ke } \\
\text { sikolog atau dokter untuk diperiksakan fisik dan psikisnya. }\end{array}$ \\
\hline 2. & $\begin{array}{l}\text { rang tua harus waspada apabila ada seseorang yang tampak lebih berminat atau } \\
\text { nemberi perhatian khusus pada anak kita atau menawarkan untuk menjaganya tanpa } \\
\text { ayaran atau bertamasya berduaan dengan anak. }\end{array}$ \\
\hline 3. & $\begin{array}{l}\text { perlu membuka komunikasi dengan ana } \\
\text { tikan hal-hal berikut: } \\
\text { waktu dan tempat yang tepat } \\
\text { in sausana nyaman } \\
\text { da bicara } \\
\text { secara langsung } \\
\text { kan dan tindaklanjuti jawaban anak } \\
\text { i menghakimi dan menyalahkan anak } \\
\text { an anak bahwa mereka tidak bersalah } \\
\text { ar } \\
\text { enang } \\
\text { a apa yang dikatakan anak } \\
\text { likan rasa aman pada anak } \\
\text { biarkan anak menyalahkan diri sendiri }\end{array}$ \\
\hline 4. & $\begin{array}{l}\text { Anak yang pernah mengalami kekerasan seksual bentuk apapun akan memiliki berbagai } \\
\text { rasa takut yang membuat mereka sulit untuk menceritakan pengalamannya, seperti: } \\
\text { a) Takut kalau pelaku mungkin akan menyakiti dirinya ataupun keluarganya } \\
\text { b) Takut orang-orang tak akan percaya dan malah berbalik menyalahkan dirinya } \\
\text { c) Khawatir bahwa orangtua akan marah atau kecewa kepada mereka } \\
\text { d) Ketakutan bahwa dengan mengungkapkan kejadian, ia akan mengganggu keluarga, } \\
\text { terutama jika pelaku merupakan kerabat dekat atau anggota keluarga sendiri } \\
\text { e) Ketakutan bahwa jika memberi tahu ia akan diambil dan dipisahkan dari keluarga } \\
\text { f) Kemampuan seorang anak untuk mengungkapkan peristiwa pelecehan atau } \\
\text { kekerasan berbeda antara satu anak dengan anak yang lainnya. Hal ini sesuai dengan } \\
\text { kemampuaan anak menurut usianya. }\end{array}$ \\
\hline
\end{tabular}

Selanjutnya tim pengabdi memberikan kesempatan kepada peserta untuk membahas materi melalui proses tanya jawab di aplikasi WhatsApp atau menelpon langsung ke tim pengabdi. Beberapa dari peserta menanyakan bentuk-bentuk kekerasan seksual yang cenderung terjadi pada anak. Selama ini mereka memahami kekerasan seksual terbatas pada tindakan pemerkosaan. Di sini tim pengabdi menjelaskan bahwa terdapat 15 bentuk kekerasan seksual menurut Komnas Perempuan. Kemudian masyarakat juga menanyakan lebih detail bagaimana langkah-langkah konkrit dalam pelaporan jika terjadi tindakan kekerasan seksual, seperti apa yang dilakukan pertama kali dan siapa yang akan dihubungi. 


\section{KESIMPULAN}

Peningkatan pemahaman orang tua telah tercapai melalui kegiatan pengabdian kepada masyarakat ini dengan telah terbangunnya kesadaran orang tua mengenai cara-cara atau upaya penanganan kekerasan seksual jika terjadi pada anak mereka. Kegiatan sejenis perlu dilakukan dalam skala yang lebih luas. Diharapkan nantinya ada gerakan masyarakat untuk pencegahan terjadinya tindakan kekerasan seksual di Kecamatan Pauh Kota Padang. Kepada masyarakat diharapkan tidak lagi enggan untuk melaporkan kasus-kasus kekerasan seksual yang terjadi di lingkungannya dan mengetahui kemana harus melaporkan. Kepada pemerintah juga diharapkan lebih sering melakukan upaya sosialisasi mengenai kekerasan seksual dan dampaknya serta memfasilitasi kegiatan-kegiatan masyarakat yang berkaitan dengan upaya-upaya pencegahan terjadinya kekerasan seksual.

\section{UCAPAN TERIMA KASIH}

Atas dukungan dari berbagai pihak terutama dari pihak kelurahan, peserta dan tim pengabdi pelaksanaan kegiatan ini berjalan lancar, disamping juga atas dukungan dana dari Fakultas Ilmu Sosial dan Ilmu Politik Universitas Andalas. Peserta dan pihak kelurahan menyampaikan apresiasinya atas pelaksanaan kegiatan ini yang dirasakan bermanfaat bagi orang tua dalam penanganan terjadinya tindakan kekerasan seksual terhadap anak.

\section{DAFTAR PUSTAKA}

Fachrina, dkk, 2019. Peran Pemerintah dalam Upaya Pencagahan kekerasan Seksual. Artikel tidak dipublikasikan, Universitas Andalas.

Macdaliza dan Fachrina, 2016. "Pandangan dan Sikap masyarakat terhadap Kekerasan Seksual”. Laporan Penelitian Fisip Unand.

Naherta, Meri, 2017."Modul Intervensi Pencagahan kekerasan Seksual terhadap Anak". Fakultas Kesehatan Masyarakat, Universitas Andalas.

Poerwandari, E. K. 2000. Kekerasan terhadap perempuan: tinjauan psikologi feministik, dalam Sudiarti Luhulima (ed) "Pemahaman bentuk-bentuk tindak kekerasan terhadap perempuan dan alternatif pemecahannya", Jakarta: Kelompok kerja “convention watch"

Undang-Undang No 23 tahun 2002 tentang Perlindungan Anak.

www.komnasperempuan.or.id/rencanastrategis/20152019, diakses tanggal 10 Desember 2020

www.liputan6.com. "Nestapa 2 Remaja di Padang Alami Pelecehan Seksual dari Sang Ayah Bertahun-tahun”, diakses tanggal 15 Juni 2020. 